\title{
Pearls of Neonatal Intertrigo in Ancient Greek and Byzantine Medicine
}

\author{
Gregory Tsoucalas ${ }^{1}$, Konstantinos Krasagakis ${ }^{2}$, Constantinos Pantos ${ }^{3}$, \\ Marianna Karamanou ${ }^{1}$
}

${ }^{1}$ University Institute of History of Medicine, Claude Bernard University Lyon, France, ${ }^{2}$ Department of Dermatology, University General Hospital of Heraklion, Heraklion, Crete, Greece, ${ }^{3}$ Department of Pharmacology, Medical School, National and Kapodistrian University of Athens, Athens, Greece

Correspondence: gregorytsoucalas@yahoo.gr Tel.: + 306945298205

Fax.: + 302421078160

Received: 22 January 2018 Accepted: 14 May 2018

Key words: Ancient Greece - Byzantium - Intertrigo - Botanology - Paediatric dermatology.

\begin{abstract}
Objective. Confirmation of knowledge of neonatal intertrigo in ancient Greek and Byzantine medicine. Method: A search of Thesaurus Linguae Graecae was conducted with the following terms as key words, "syggama", "xyggauma", "paratrimma" and "ektrimma". Results: Ancient Greek medico-philosophers introduced therapeutic measures based upon herbs and minerals, while a similar therapeutic approach was also used by the Byzantines. Hippocrates of Kos (460-377) was among the first to introduce written instructions, also proposing preventive treatment with palliative and aromatic herbs. Cataplasms, thalassotherapy, and fumigation were used, combined with hygienic measures in the affected area. Chalk powder was also prescribed to absorb moisture. Conclusion. The main principles in the treatment of intertrigo remain the same, celebrating the ancient Greeks' methodology and rationalism.
\end{abstract}

\section{Introduction}

Neonatal intertrigo is an inflammation of the skin folds, of irritant or infectious aetiology. Neonates and infants are more predisposed towards intertrigo as they have abundant subcutaneous tissue which prevents the folds from airing out. Prolonged contact with an irritant, mainly detergents, urine, faeces and fragrances, affects the skin properties and enhances permeability to exogenous materials, thus increasing transepidermal permeability and susceptibility to friction. Therefore, friction between the skin folds, coupled with maceration, due to reduced evaporation of sweat and overgrowth of bacteria (S. aureus, Strep. pyogenes) and fungi (Candida albicans), contribute to the development of erythema, pruritus, maceration and erosions, which may be quite persistent. Therapeutically, gentle cleaning, keeping the affected area dry, and topical barrier agents (zinc oxide paste) can be very effective. In some cases, imidazole lotions and antibacterial agents, such as mupirocin cream, and topical corticosteroids may also be administered. However, the importance of prevention, in terms of cleanliness, dryness and use of protective barriers, should be always stressed (1-3).

Intertrigo, as a term, comes from the Latin words "inter" which means "in between" 
and "terrere" which means "to rub" (4). It was a well-recognized affliction in Ancient Greece, as Hippocrates (460-377) and his followers were among the first authors to describe it, in the "Corpus Hippocraticum" (5). The terms used by the Greek medicophilosophers in antiquity were "syggama"

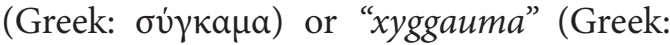

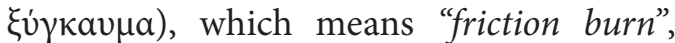

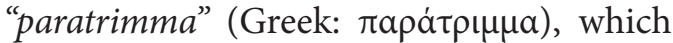
means "rubbing between two surfaces" and

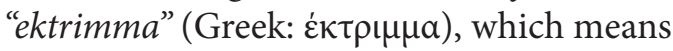
"a lesion caused by friction" (6).

With the goal of discovering the knowledge of the ancient Greeks and Byzantines regarding intertrigo, our study gathers all the text fragments found in the TLG (Thesaurus Linguae Graecae), a digital collection of surviving texts written in Greek, after a search using those terms as key words.

\section{Neonatal Intertrigo in Ancient Greek and Byzantine Dermatology}

Neonatal intetrigo has been recognized since antiquity, and ancient Greek physicians proposed various therapeutic approaches (6). In the $5^{\text {th }}$ century BC, Hippocrates and his followers first mentioned the importance of prevention, and proposed cataplasms based on a mixture of aromatic herbs (On Diseases, 4th Book) (7). Furthermore, he introduced seawater bathing, or steam bathing (boiled seawater) for alleviation of pruritus (On the Use of Liquids) (8). In his opinion, precautionary measures should be administered soon after birth to avoid intertrigo

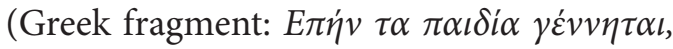

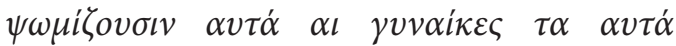
$\varphi \alpha \dot{\rho} \mu \alpha \kappa \alpha \ldots \kappa \alpha \iota \mu \eta \xi v \gamma \kappa \alpha v \theta \dot{\eta})$ (7).

Centuries later, the distinguished Greek pharmacologist and leading expert in therapeutic botanology, Dioscorides (40-90) proposed, for treatment of intertrigo, a mixture of Myrtus communis, Lycium barbarum, Plumbago capensis, chalcopyrite, white lead, and litharge. A palliative watery poultice was used as a cataplasm; aromatic oils, or even a powder of minerals and dried natural herbs were also applied (9). Dioscorides' view was adopted by Galen (130-201), who was considering litharge to be an amazing "remedy

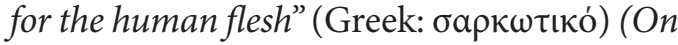
the Composition of Drugs According to Places) (10). In his turn, the Byzantine physician Oribasius (320-400), having mentioned both Dioscoride's and Galen's views, suggested that intertrigo lesions "should be covered with dry Myrtus, Cyperus Rotundus and rose hip, all stirred with some aroma" (Greek

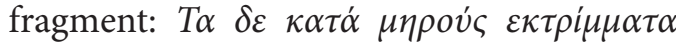

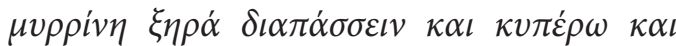

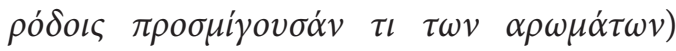
(11). The famous Byzantine physician and medical writer, Aetius of Amida (502-575), proposed exactly the same treatment (Greek

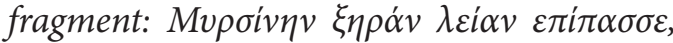

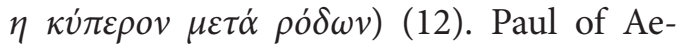
gina (625-690), whose paediatric work was based upon Oribasius' treatise, also had the same opinion. According to his work, he proposed the topical application of "Balaus-

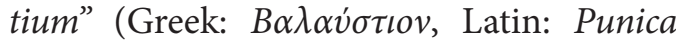
granatum, varietas plena major), the double flowered pomegranate tree, a plant with astringent properties in its bark, leaves and blooms, to cure intertrigo (13).

Oribasius and the Arab-Islamic physician Al Rhazi (854-925) mentioned that Soranus of Ephesus (98-138), the founder of obstetrics and gynaecology, and an expert in paediatrics, had dealt with neonatal intertrigo in his treatise entitled "On the

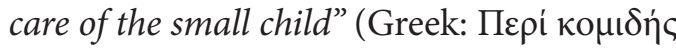
$\pi a ı \delta ı$ ', Arabic: Tadbir al atfal) $(11,14)$. In his turn, Avicenna (980-1037), adopted and proposed the ancient Greek treatment for intertrigo in his masterpiece, "The Canon of Medicine" (Arabic: al-Qanun fi al-Tibb) (15, 16). Centuries later, the Swiss physician and alchemist Philippus Aureolus Theophrastus Bombastus Von Hohenheim (1493-1541), 
known as Paracelsus, mentioned in his work that the ancient Greeks used herb Helleborus niger (Ranunculaceae family), a well-known plant in antiquity, to treat skin irritations such as intertrigo (17). A reference was also made to its rose like flowers, while no other such citation is available.

\section{Discussion}

Ancient Greek medico-philosophers divided cutaneous diseases into psoriasic, leprotic and leichen. The term psora referred to itching and erythema, depicting moist pustular ulcerated conditions and eczematous like eruptions. The term lepra, from the Greek words "lopos" (Greek: $\lambda$ ó $\pi$ ○, the epidermis) and "lepo" (Greek: $\lambda \dot{\varepsilon} \pi \omega$, remove the outer layer), referred to scaly conditions, while leichen represented skin growths held on by adhesion to the base $(5,18)$. So, intertrigo was classified as a "psoriasic" dermatological disease and physicians proposed the treatment of so called neonatal psora, as soon as it appeared (6).

Since environmental interaction with the human's body homeostasis has been known from the Hippocratic era (6), there is a great possibility that Soranus of Ephesus and Paul of Aegina differentiated intertrigo from allergic and irritant contact dermatitis, which usually presented with more intense pruritus and signs of eczema (from the Greek words "ec": over, "ze": boiling, and " $m a$ ": result of, thus describing a more superficial reaction), a more severe condition than the simple erythematous lesion of intertrigo. Thus, in cases of eczema, they suggested "hot pads with a rich suffuse of boiled olive oil are useful, mixed with a small quantity of melted wax in order for the mix to be thicker, for longer adherence" $(19,20)$.

A series of herbs were harnessed by the Greeks in antiquity to treat neonatal intertrigo (Figure 1).
Among them, "Myrtus communis" (Greek: Múpтos o кoเvós) of the family "Myrtaceae" represented the main ingredient for preparations against cutaneous affections. It is an aromatic evergreen perennial shrub or small tree, with small foliage and deep fissured bark. Its name, "Myrtus", signifies a common plant growing in groups. Myrtle occupied a prominent place in the writings of Hippocrates, Pliny (23-79), Dioscorides, Galen and the Arabian writers. According to them, the leaves and fruit were therapeutic for several diseases, including intertrigo (21-23). Nowadays, Myrtle is known to have antibacterial and antifungal properties, which exhibit remarkable activity against several fungal strains (24). Cyperus

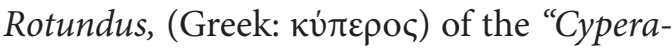
ceae" family, was used from the Mycenaean era as a purifying agent, a skin reviving, healing factor, and herb regulator of the body's humours (blood, phlegm, yellow bile, black bile) $(13,25)$. It is now known that Cuperus has antibacterial activities against Staphylococcus epidermidis, Bacillus cereus, Pseudomonas aeruginosa, Escherichia coli (26). "Ly-

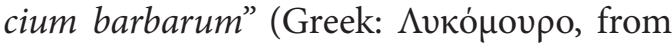
the ancient southern Anatolian region of Lycia) was also widely used by the ancient Greeks as an anti-inflammatory agent (9). Flavonoids isolated from Lycium barbarum fruits have anti-inflammatory and anti-angiogenic effects (27). "Plumbago capensis"

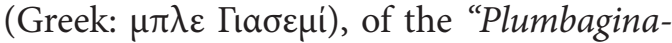
ceae" family, was used for the wood's healing capacities, which are appreciated even now, as well as its antibacterial properties, especially against Staphylococcus aureus (28). Furthermore, some studies mention its strong antifungal activity, equivalent to that of voriconazole (29). Rose hip (ancient

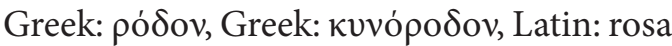
canina) is today a product in cosmetics, included not only among the fragrance substances but also in skin conditioning agents (30). On the other hand, Punica granatum 


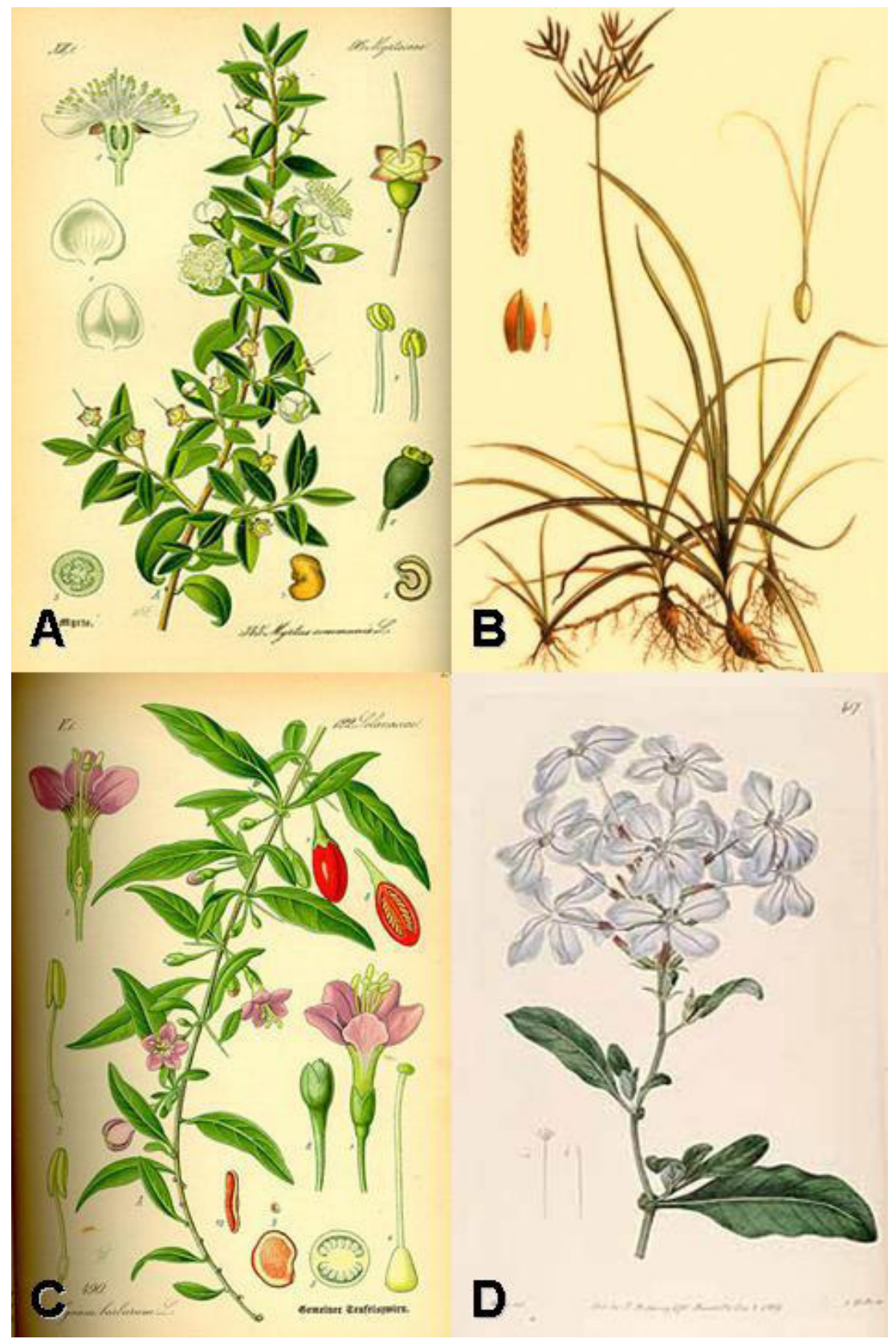

Figure 1. A: Myrtus communis, B: Cyperus Rotundus, C: Lycium barbarum, D: Plumbago capensis. A, C: colloured illustrations, Flora von Deutschland, Osterreich und der Schweiz, 1885, B, D: colloured illustrations, Mills C, Hortus Camdenensis, 1848.

is proposed as an anti-infection and antiworm killer in modern female cosmetics (31). Meanwhile, "Heleborus niger" (Figure 2) for the ancient Greeks was a herb widely used against mild and severe skin diseases, from intertrigo to leprosy (32).
Strangely, the perennial plant is nowadays considered to be poisonous, while especially its roots may cause a skin irritation and blistering. In medieval Europe it was used in a small dosage as an anti-parasite drug (33). There is the possibility that there was another 


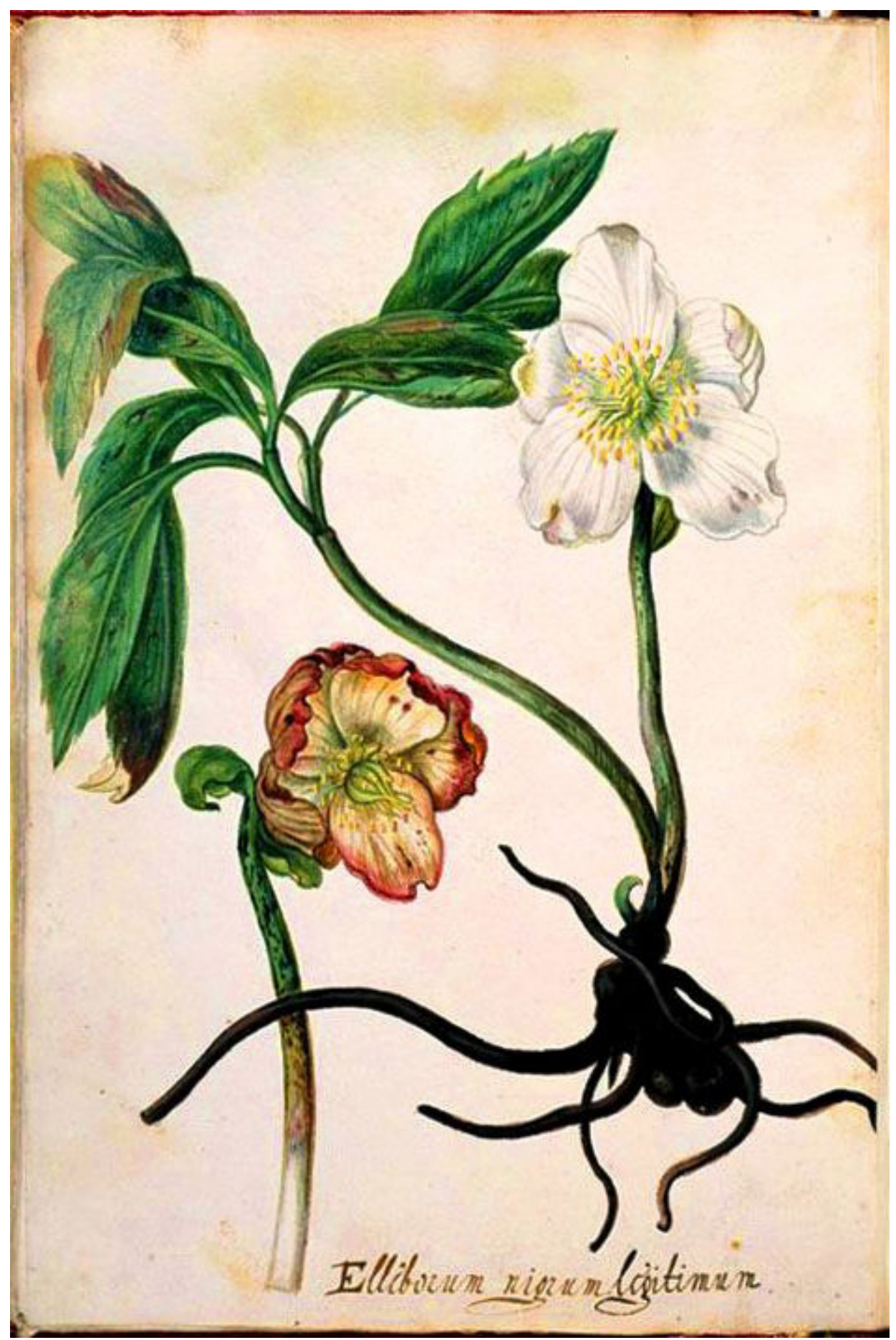

Figure 2. Helleborus niger, Kräuterbuch, Actaea spicata, 1914.

species in Greek antiquity, less irritating than the "Helleborus niger" noted by Paracelsus, or it was perhaps used in poultices, or after some process which could have altered its side effects. It seems that Greek physicians in antiquity, experts in botanology, observed nature and the properties of herbs, used them to treat intertrigo in the form of 
Table 1. Therapeutic ingredients used in ancient Greek and Byzantine dermatology and their current use.

\begin{tabular}{|c|c|c|c|}
\hline No & Ingredient & Ancient Greek and Byzantine dermatology & Modern dermatology \\
\hline 1. & Myrtus communis & Skin therapeutic agent & $\begin{array}{l}\text { Antibacterial } \\
\text { Antifungal }\end{array}$ \\
\hline 2. & Cyperus Rotundus & $\begin{array}{l}\text { Skin purifying agent } \\
\text { Skin reviving and healing agent } \\
\text { Humour regulator }\end{array}$ & Antibacterial \\
\hline 3. & Lycium barbarum & Anti-inflammatory & Anti-inflammatory \\
\hline 4. & Plumbago capensis & Healing wood capacity & $\begin{array}{l}\text { Antibacterial } \\
\text { Antifungal } \\
\text { Repairing skin liaisons }\end{array}$ \\
\hline 5. & White lead & $\begin{array}{l}\text { Base in powders } \\
\text { Oil ingredient } \\
\text { Skin healing agent } \\
\text { Skin whitener } \\
\text { Hair colouring }\end{array}$ & $\begin{array}{l}\text { Basic acetate salt of lead as an ingredient in } \\
\text { Water Soft Aluminium } \\
\text { Men's hair colouring }\end{array}$ \\
\hline 6. & Litharge & $\begin{array}{l}\text { Skin healing agent } \\
\text { Tumours' lytic activity }\end{array}$ & - \\
\hline 7. & Thalassotherapy & Skin purifying and palliative agent & Hypertonic solution of sea minerals \\
\hline 8. & Chalk powder & $\begin{array}{l}\text { Base in powders } \\
\text { Moisture absorbent } \\
\text { Astringent agent } \\
\text { Cosmetics (eye colouring) }\end{array}$ & Talc ingredient \\
\hline
\end{tabular}

cataplasms, and practised dermatology in an almost scientific manner.

Thalassotherapy, introduced by the ancient Greeks, is a method still in use. A hypertonic solution of sea water penetrates skin lesions. Trace elements of magnesium, potassium, calcium, sodium and iodide found in seawater are believed to be absorbed through the skin. Thalassotherapy was applied in various forms: as showers of warmed sea water, inhalation of sea fog, or fumigation (34).

White lead powder was completely abandoned during the Byzantine era due to several deaths provoked by slow lead poisoning, a situation already known at least during the age of Pliny (23-79), and it was replaced by chalk powder, a soft, white, porous, sedimentary carbonate rock, a form of limestone, composed of the mineral calcite, well-known for its use in cosmetics in Greek antiquity (35). This powder, believed to have astringent properties, also had the ability to absorb moisture locally, but was also used as a base for the preparation of cataplasms. It was used extensively in the Byzantine era in the treatment of intertrigo, skin ulcers and burns $(6,36-38)$. Litharge (lead monoxide) was used as a lytic agent in tumour formations, and as a healing agent in skin ulcerations and intertrigo. Dioscorides believed that it also had the property of promoting cicatrisation, and it was also proposed as an anti-wrinkle agent and skin whitener in cases of melasma $(9,13,39-41)$. Surprisingly, honey and olive oil, which were used in several cosmetic and skin preparations in antiquity, were completely neglected in the treatment of intertrigo (6). Finally, it is worth mentioning that the ancient Greek and Byzantine physicians' treatment for intertrigo ( $\mathrm{Ta}$ ble 1) was adopted in the medieval period by the Orthodox Monasteries in Russia, which operated as health centres (42). 


\section{Conclusion}

The most significant medico-philosophers of Greek antiquity mentioned neonatal intertrigo, and suggested herbal and mineral based therapeutic approaches, thus proving not only their knowledge of pharmacology, but also their rationalism in the treatment of skin diseases. Similarly, preventive and curative measures for this type of dermatitis, initially mentioned in ancient Greek medical texts, continued in the Byzantine era and have surprisingly survived until the present day in the treatment of intertrigo.

\section{What is already known on this topic}

Intertrigo primarily affects neonates and infants. Neonatal intertrigo is a well studied entity, known since antiquity. Its causes, symptoms and treatment have all been adequately researched.

\section{What this study adds}

Our knowledge concerning intertrigo in Greek antiquity is somehow vague. This historical review gathers and sheds light on the available knowledge in the treatises of ancient Greek and Byzantine medico-philosophers. A comparison between ancient and modern treatment surprisingly reveals strong similarities.

Authors' contributions: Conception and design: GT; Acquisition, analysis and interpretation of data: GT, KK, CP and MK; Drafting the article: GT; Revising it critically for important intellectual content: $\mathrm{KK}, \mathrm{CP}$ and MK; Approved final version of the manuscript: MK.

Conflict of interest: The authors declare that they have no conflict of interest.

\section{References}

1. Hadi SA. Cutaneous Disorders of the Newborn. In: Textbook of Clinical Pediatrics. 2nd ed. Berlin: Springer; 2012.

2. Plewing G, Wolff $\mathrm{HH}$, Landthaler $\mathrm{M}$, editors. Braun-Falco's Dermatology. Heidelberg: Springer; 2009.

3. Teng J, Marqueling AL, Benjamin L, editors. Therapy in Pediatric Dermatology: Management of Pediatric Skin Disease. Berlin: Springer; 2017.
4. Wain H. The story behind the word: some interesting origins of medical terms. Illinois: Thomas; 1958.

5. Weinberg JM. Treatment of Psoriasis. Basel: Springer Science \& Business Media; 2008.

6. Tsoukalas I. Paediatrics and Neonatology in ancient Greece and Byzantium. Chania \& Thessaloniki: Science Press; 2004.

7. Hippocrates. On diseases Book IV [in French]. In: É. Littré, editor. Oeuvres complètes d'Hippocrate, vol. 7. Paris: Baillière; 1851.

8. Hippocrates. On the use of liquids [in French]. In: É. Littré, editor. Oeuvres complètes d'Hippocrate, vol. 6. Paris: Baillière; 1849

9. Dioscorides Pedanius Med. On Medical Material [in French]. In: M. Wellmann, editor. Pedanii Dioscuridis Anazarbei de materia medica libri quinque, 3 vols. Berlin: Weidmann; 1:1907; 2:1906; 3:1914.

10. Galen. On the Powers and Mixtures of Simple Drugs \& On the Composition of Medical Compounds according to Places [in Latin]. In C.G. Kühn, editor. Claudii Galeni opera omnia, vol. 14. Leipzig: Knobloch; 1827.

11. Oribasius of Pergamon. Oribasius' Works Book V [in French], vol IV. Paris: Bussemaker \& Daremberg; 1851-1876.

12. Aetius A. Thigh intertrigo, Iatricorum liber I-IV [in French]. Paris: Klincksieck; 1892.

13. Paulus Aegineta. Thigh intertrigo, Books I-VII, Adams Francis (trans.). London: Sydenham Society; 1796-1861.

14. Al-Razi. On the Treatment of Small Children (De curis puerorum). Leiden: Brill; 2015.

15. Bakhtiar L. The Canon of Medicine. Avicenna Adapted by Laleh Bakhtiar. Great Books of the Islamic World Inc. Chicago, IL: Kazi Publications Inc; 1999.

16. Modanlou HD. Medical Care of Children during the Golden Age of Islamic Medicine. Arch Iran Med. 2015;18(4):263-5.

17. Paracelsus. Opera Omnia. London: Wilson; 1835.

18. Wilson E. Lectures on Dermatology. The Medical times and Gazzete Journal. (London) 1870;1: 169174.

19. Ilberg J. Sorani Gynaeciorum libri iv, The signs of a fracture, the bandages, Hippocrates biography. In: Greek Medical Corpus, vol. 4. Leipzig: Teubner; 1927.

20. Paulus Aegineta. On itching Books I-VII, Adams Francis (trans.). London: Sydenham Society; 1796-1861. 
21. Sumbul S, Ahmad A, Asif M, Akhtar M. Myrtus communis Linn. Indian J Nat Prod Resour. 2011;2(4):395-402.

22. Kirtikar KR, Basu BD. Indian Medicinal Plants, 3rd ed. Dehradun: International Book Distributors; 1988

23. Stuart M. The Encyclopaedia of Herbs and Herbalism. New York: Crescent Books; 1979.

24. Ben Hsouna A, Hamdi N, Miladi R, Abdelkafi S. Myrtus communis essential oil: chemical composition and antimicrobial activities against food spoilage pathogens. Chem Biodivers. 2014;11(4):571-80.

25. Liddell HG, Robert S. A Greek-English Lexicon [buckwheat]. New York, Chicago, Cincinnati: American Book Company; 1901.

26. Sharma SK, Singh AP. Antimicrobial investigations on rhizomes of Cyperus rotundus Linn. Der Pharmacia Lettre. 2011;3(3):427-31.

27. Wu WB, Hung DK, Chang FW, Ong ET, Chen BH. Anti-inflammatory and anti-angiogenic effects of flavonoids isolated from Lycium barbarum Linnaeus on human umbilical vein endothelial cells. Food Funct. 2012;3(10):1068-81.

28. Dibyajyoti S, Swati P. Antibacterial activity of Plumbago indica. Turk J Pharm Sci. 2014;11(2):217-22.

29. Jagan Arokiaraj S, Selvarani P. Evaluation of Antifungal efficacy of Plumbago sp. against clinically isolated fluconazole resistant Candida albicans. International Journal of Applied Pure Science and Agriculture. 2016;2(9):8-12.

30. Nikitakis, J, Breslawec HP. International Cosmetic Ingredient Dictionary and Handbook. 14th ed. Washington: Personal Care Products Council; 2014.
31. Hobby E. The Birth of Mankind: Otherwise Named, The Woman's Book. New York: Routledge; 2017.

32. Olive Rayer PF. A Theoretical and Practical Treatise on the Diseases of the Skin. Philadelphia: Carey and Hart; 1845.

33. Michael Balick. Rodale's 21st-Century Herbal: A Practical Guide for Healthy Living Using Nature's Most Powerful Plants. New York: Rodale; 2014.

34. Riyaz N, Arakkal FR. Spa therapy in dermatology. Indian Journal of Dermatology, Venereology and Leprology. 2011;77(2):128-34.

35. Waldron HA. Lead poisoning in the ancient world. Med Hist. 1973;17(4):391-9.

36. Parani MG. Cosmetics, Byzantine. In: The Encyclopaedia of Ancient History. Malden: WileyBlackwell; 2012.

37. Moore G. Ancient Greece: A Comprehensive Resource for the Active Study of Ancient Greece. Balcatta: RIC Publications; 2000.

38. Americanized Encyclopedia Britannica, Revised and Amended. Chicago: Belford-Clarke Co; 1890.

39. Hooper R. Lexicon Medicum. New York: Harper \& Brothers; 1845.

40. Perogiani C, Tsoukalas G, Tsoukalas I. Pediatric dermatologic diseases in ancient Greece. J Am Acad Dermatol. 2013;68(4 Suppl 1):AB176.

41. Sgantzos M, Tsoucalas G, Karamanou M, Giatsiou S, Tsoukalas I, Androutsos G. Hippocrates on Pediatric Dermatology. Pediatr Dermatol. 2015;32(5):600-3.

42. Melnychuk IA, Melnychuk AA. Medicine of Old Russian monasteries from the perspective of a modern medical practice. Grani. 2017;2(142):615. 